\title{
How does family management affect innovation investment propensity? The key role of innovation impulses
}

\begin{abstract}
We investigate the relationship between family management and innovation investment propensity in family firms through analyzing the effect of two innovation impulses: demandpull and technology-push. Extending the technology-push/demand-pull framework to the context of family firms, and adopting a direct measure of firms' innovation investment propensity, we test our hypotheses on a sample of 1,093 Italian small and medium-sized family firms. Our results show that both the demand-pull and technology-push innovation impulses moderate the relationship between family management and the firms' propensity to invest in innovation, reducing the negative effect exerted by family management on family firms' innovation investment propensity. Moreover, our evidence shows that family firms' innovation investments are more sensitive to the demand-pull than the technology-push impulse. Overall, our findings suggest to practitioners and policymakers that family firm innovation impulses are important contingencies that need to be taken into account when making innovation investment decisions.
\end{abstract}

Keywords: Family business, Family firms, Family management, Innovation.

JEL: L20, L26, O32

\section{Introduction}

Innovation is an important determinant of sustained firm performance (Blundell, Griffiths, \& Van Reenen, 1999) and a key driver of technological progress and economic growth (Cohen \& Levin, 1989; Levin et al., 1987). However, successful innovation processes require financial and knowledge resources, accepting a degree of risk ensuing from the difficulty of predicting the payoffs of investment projects, and uncertainty over customer acceptance, market and 
competitive dynamics. Thus, understanding which factors drive (or inhibit) firms' innovation investment decisions has become increasingly relevant in the management literature and a key priority in policymakers' agenda.

In recent years, technological innovativeness in family firms - the most ubiquitous form of business organization in any world economy (La Porta, Lopez-de-Silanes, \& Shleifer, 1999) has become a topic of growing interest (Filser, De Massis, Gast, Kraus, \& Niemand, 2016). There are strong theoretical reasons to expect that the determinants (and effects) of technological innovation differ in family and non-family firms (De Massis, Frattini, \& Lichtenthaler, 2013; De Massis, Frattini, Pizzurno, \& Cassia, 2015; Kraus, Pohjola, \& Koponen, 2012). Existing studies are consistent in highlighting a negative relationship between family involvement and technological innovation inputs (R\&D investments) (e.g., Chen \& Hsu, 2009; Block, 2012; Kotlar, De Massis, Frattini, Bianchi, \& Fang, 2013; Matzler, Fang, Chrisman, \& De Massis, 2015; Munari, Oriani, \& Sobrero, 2010; Muñoz-Bullon \& SanchezBueno, 2011; Sirmon, Arregle, Hitt, \& Webb, 2008).

This negative relationship is explained by two main theoretical arguments. Based on agency theory, it is argued that family firms adopt a conservative financial strategy, with a strong preference for internal financial resources (Romano, Tanewski, \& Smyrnios, 2001; Sirmon \& Hitt, 2003) to safeguard family control of the business (Le Breton-Miller \& Miller, 2006). This behavior creates financial constraints that could impede investing in innovation (Carney, 2005). Moreover, family firm behavior is distinctively driven by economic and non-economic goals (Chrisman, Chua, Pearson, \& Barnett, 2012; Kotlar \& De Massis, 2013; Randolph, Alexander, Debicki, \& Zajkowski, 2019). To protect the business for future generations and their noneconomic utilities (Gómez-Mejía, Haynes, Núñez-Nickel, Jacobson, \& Moyano-Fuentes, 2007; Kotlar, Signori, De Massis, \& Vismara, 2018), family firms tend to be more risk averse (Naldi, Nordqvist, Sjöberg, \& Wiklund, 2007) and prefer investments that protect the cash flow 
of the current business (Morck \& Yeung, 2003). The pursuit of these goals can lead to restrained investments in innovation (Astrachan \& Jaskiewicz, 2008; Chua, Chrisman, \& Steiner, 2003; Filser, Brem, Gast, Kraus, \& Calabrò, 2018).

Furthermore, the literature suggests that such behaviors are more likely in family-managed firms, since family involvement in management increases the family members' ability to influence the business strategy, reducing non-family members' discretion to act (Zahra, 2005), and strengthening the firm's focus on pursuing non-economic goals (Block, Miller, Jaskiewicz, \& Spiegel, 2013).

Although these arguments have significantly contributed to improving our understanding of the innovation behavior of family firms, they provide only a partial explanation of family firms' propensity to invest in innovation activities for at least two reasons. First, prior studies do not consider the factors that create the impulse (Brem \& Voigt, 2009) to invest in innovative activities, that is, whether innovation is demand-pulled (DP) and/or technology-pushed (TP). The innovation management literature widely recognizes that DP and TP are the main factors influencing the firm's rate and direction of technological innovation (Di Stefano, Gambardella, \& Verona, 2012; Mowery \& Rosenberg, 1979; Myers \& Marquis, 1969; Rosenberg, 1982; Schmookler, 1966; von Hippel, 1976). Although the DP-TP approach has been widely used in analyzing the innovation behavior of non-family businesses (of different sizes and in different industries $)^{1}$, to our best knowledge, no studies explore the DP and TP innovation sources in the context of firms with family involvement.

The joint consideration of the DP-TP drivers and family involvement could lead to a clearer understanding of family firms' innovation behavior given that DP and TP have very different characteristics in terms of degrees of risk, time horizon of expected profits, technological uncertainty, level of $R \& D$ expenditure, and duration of $R \& D$ activities (Herstatt \& Lettl, 2004).

\footnotetext{
${ }^{1}$ For a review of the sources of innovation in the TP and DP perspective, see Di Stefano et al. (2012).
} 
Moreover, DP and TP are unable in themselves to determine innovation investments in a firm; they require the intention and willingness to engage in innovation processes based either on technological knowledge or on market demand. Accordingly, we suggest that in family firms, the propensity to invest in innovation is the result of the joint action of family management and the specific source of innovation considered. This perspective leads us to unveil the circumstances under which family management might exert a strong or weak effect on the propensity to invest in innovation, helping policymakers select the right actions with the potential to stimulate innovation investments in family-managed firms (TP and/or DP policies).

Second, existing studies generally refer to $R \& D$ investments as a proxy of the propensity to invest in innovation. Although this is a requirement for creating or improving new products or technologies, $R \& D$ investments could be a non-exhaustive and underestimated proxy of the firm's propensity to invest in innovation. In fact, innovation investments might also relate to other types of expenditure aimed at creating new products or improving processes, and R\&D expenditure is systematically underestimated in small firms (Archibugi \& Pianta, 1996; Patel \& Pavitt, 1995). In particular, recent literature highlights that "splitting the innovation input stage in two parts" (the decision to invest in innovation and the amount of innovation investment) avoids a potential interpretation bias of innovation in family firms (Classen, Carree, Van Gils, \& Peters, 2014, p. 596). For instance, family SMEs have a high propensity to invest in innovation despite low R\&D intensity (especially compared to non-family firms) (Classen et al., 2014).

Moreover, R\&D projects are human-capital intensive (Hall \& Lerner, 2010), long term, and characterized by high risk and uncertain returns (Holmstrom, 1989). Thus, R\&D investments would seem more appropriate to reflect investments in technology-pushed rather than marketpulled innovation. These aspects highlight that the use of a direct measure of the propensity to invest in innovation can provide a more exhaustive and precise evaluation of family firms' 
innovation behavior in the input stage of the innovation process.

Based on these considerations, this study attempts to advance our understanding of the effect of family management on family firms' propensity to invest in innovation by integrating the technology push/demand-pull framework in the context of family firms, and adopting a direct measure of firms' propensity to invest in innovation. Specifically, we propose a research model that explores the moderating effect of demand heterogeneity (as a DP factor) and technological capabilities (as a TP factor) in the relationship between the degree of family involvement in management and family firms’ propensity to invest in innovation activities.

Using a sample of 1,093 Italian family firms operating in the manufacturing industries, our logistic regression model predicts that DP and TP moderate the relationship between family management and firms' propensity to undertake innovation investments. Specifically, when the DP or TP sources of innovation increase, the negative effect of family management measured through family involvement in the top management team (FTMT) - on the propensity to invest in innovation weakens. However, our results show that DP is a key contingency of investment innovation propensity and a key factor of weakening the negative effect of FTMT.

Our analysis contributes to the literature on technological innovation in family firms and to general innovation management studies in several ways. First, our study provides a more comprehensive and fine-grained understanding of the effect of family management on innovation investments in family firms. While previous studies mostly analyze its direct effect on innovation input or its mediating role in the relationship between innovation input, output, and performance (e.g., Diéguez-Soto, Manzaneque, \& Rojo-Ramírez, 2016), our research aims to clarify the circumstances under which family management might exert a strong or weak effect on the propensity to invest in innovation, specifically, whether and how different innovation impulses (DP and/or TP) moderate this effect.

Identifying which factors moderate the relationship between family management and the 
propensity to invest in innovation would allow a better interpretation of the innovation behavior of family firms compared to non-family firms, as well as the heterogeneity among family firms.

Moreover, in the field of empirical research on innovation in family firms, this is the first study to use a direct measure of firm propensity to invest in innovation. As such, it overcomes the limitations associated with using R\&D intensity in prior research, offering a more accurate assessment of the propensity of family firms to invest in innovation.

Second, our study contributes to bridging the existing knowledge gap at the intersection of the innovation management and family firm fields of study (Chrisman, Chua, De Massis, Frattini, \& Wright, 2015; De Massis et al., 2013; Kotlar, De Massis, Frattini, \& Kammerlander, 2019). The approaches and perspectives developed in the innovation management domain can be usefully extended to family firms to better interpret the decisions to invest in innovation and, more generally, the mechanisms behind the innovation behavior of these firms.

In particular, our paper proposes a research model that integrates the push-pull framework developed in the innovation management literature in the context of family managed firms to better understand which factors drive or inhibit their propensity to invest in innovation.

Third, in the general field of innovation management, our study offers two main contributions. Specifically, in the debate on the juxtaposition between technology and demand as sources of innovation and/or their complementary role (Di Stefano et al., 2012), our results suggest that in family managed firms, the demand-pull factor appears to be prevalent in determining investments in innovation, thus suggesting that the role of the two sources of innovation may differ depending on the particular type of firm and its specific characteristics (i.e., not only the sector). Moreover, our study contributes to knowledge on the mechanisms that enable a firm to leverage different sources of innovation (Di Stefano et al., 2012). Indeed, our model shows that in the context of family firms, the DP and TP sources of innovation are able to influence the propensity to invest in innovation by reducing the negative effect of family 
management on firms' propensity to invest in innovation.

\section{Theoretical framework and hypotheses}

\subsection{Effect of family management on innovation inputs}

Research on innovation in family firms highlights that the distinctive nature of these firms influences innovation inputs and outputs (Calabrò et al., 2018; De Massis, Sharma, Chua, \& Chrisman, 2012; De Massis et al., 2013; Duran, Kammerlander, Van Essen, \& Zellweger, 2016; Roessl, Fink, \& Kraus, 2010). These studies are largely consistent in showing that family management negatively influences technological innovation inputs (e.g., Block, 2012; Chen \& Hsu, 2009; Kotlar et al., 2013; Matzler, Veider, Hautz, \& Stadler, 2015; Munari et al., 2010; Muñoz-Bullon \& Sanchez-Bueno, 2011; Sirmon et al., 2008).

The family's intention to maintain substantial control over the firm (Carney 2005) and pursue non-financial goals (De Massis, Kotlar, Mazzola, Minola, \& Sciascia, 2018; GómezMejía et al., 2007) are the main reasons that lead respectively to financial constraints (Le Breton-Miller \& Miller, 2006; Romano et al., 2001) and risk aversion (Naldi et al., 2007), which may restrain investments in innovation (Astrachan \& Jaskiewicz, 2008; Chua et al., 2003). These effects appear to be more likely when family members are involved in the top management team (FTMT). The literature suggests that a higher number of family members in the TMT reduces the non-family managers' discretion and freedom to act (Zahra, 2005). Moreover, it increases the firm's focus on non-economic goals and the tendency to protect the family wealth due to having a more direct influence on the firm's strategy (Block et al., 2013). Kraiczy, Hack, and Kellermans (2014) focus on the influence of family involvement in the TMT on the firm's new product portfolio, highlighting that FTMT strongly influences investment decisions in innovation.

Specifically, FTMT may affect its "innovation orientation", defined as the "senior executive's commitment to, and support for, innovation" (Zahra \& Fescina, 1991, p. 16), and 
"the behavioural intentions of TMT members as a group regarding their willingness to engage in innovative activities" (Kraiczy et al., 2014, p. 1066). In other words, the higher the ratio of family members involved in the TMT, the more negative the effect of TMT innovation orientation on new product portfolio performance, and hence on TMT decisions regarding the resources to be invested in each new product (Kraiczy et al., 2014). Following the same perspective, we argue that family involvement in the TMT endows family members with higher discretion to act. Accordingly, they will be more able to influence the TMT innovation orientation concerning investments in innovation activities.

Family management is likely to strengthen the firm's focus on pursuing non-economic goals (Block et al., 2013). As a result, family managers might take decisions based on protecting and preserving the family's power and authority, even at the cost of losing potential economic benefits (Kotlar et al., 2013; Kotlar, Fang, De Massis, \& Frattini, 2014b) resulting from investments in innovation activities (Matzler et al., 2015). To protect their shareholding voting rights and thus their discretion to act, family managers are less willing to share control with non-family investors. This behavior may create financial constraints and lead to reduced investments in innovation (Carney, 2005), which often require external funding (Duran et al., 2016). Moreover, the literature suggests that family-managed firms invest less intensively in innovation than non-family managed firms (Classen et al., 2014), perhaps because family managers increase the firm's risk aversion to protect the family wealth (Zahra, 2005).

Indeed, a higher presence of family members in the TMT leads to greater overlap between ownership and management, and thus the closer identification of the family wealth with the firm's assets. This in turn reduces the propensity of family firms to invest in innovation (Sciascia, Nordqvist, Mazzola, \& De Massis, 2015). Moreover, a high degree of family management is acknowledged to generate more risk aversion when making decisions, especially when the payoffs of the innovation investments will manifest in the long run and are 
more difficult to predict (Sorescu, Chandy, \& Prabhu, 2003).

These arguments are consistent with recent empirical studies showing that family management negatively influences innovation inputs. For example, Matzler et al. (2015), in their recent study of large German publicly traded firms, find that family management has a negative effect on innovation inputs, suggesting that family members are risk-averse and reluctant to invest in innovation. Chrisman \& Patel (2012), in their study on publicly-held manufacturing firms, highlight that compared to non-family firms, family firms (defined based on ownership and family involvement in governance and management) tend to invest less in R\&D due to owners and managers seeking to avoid perceived threats to their socioemotional wealth. Therefore, based on this literature, we propose the following hypothesis:

H1. There is a negative association between family management and family firms' propensity to invest in innovation.

\subsection{The demand-pull and technology-push perspectives}

Recent empirical studies in innovation management highlight the relevance of combining the demand-pull (DP) and the technology-push (TP) perspectives into a unified framework to analyze the innovation behavior of firms (e.g., Crépon, Duguet, \& Mairesse, 1998; Dosi \& Nelson, 2013; García-Quevedo, Pellegrino, \& Vivarelli, 2014). These two opposing perspectives are largely used to explain the sources that influence the firm's rate and direction of innovation (Mowery \& Rosenberg, 1979; Myers \& Marquis, 1969; von Hippel, 1976; Rosenberg, 1982; Schmookler, 1966). However, Di Stefano et al.'s (2012) recent literature review advocates their equal consideration.

Distinctively, the DP perspective identifies market and consumer needs as the main sources of innovation driven by the firm's recognition and intention to satisfy these needs (Mowery \& Rosenberg, 1979; Scherer, 1982; Schmookler, 1966). Factors such as demand heterogeneity (Adner \& Levinthal, 2001; von Hippel, 2005), consumers in different geographic markets (Piva 
\& Vivarelli, 2007; Priem, Li, \& Carr, 2012; Xie \& Li, 2015), or potential new markets (Vernon, 1966) are demand-pulled impulses that may create opportunities for firms to invest in innovation activities.

On the other hand, the TP perspective proposes that research activities aimed at developing new technology and its commercialization drive innovation (Mowery \& Rosenberg 1979; Rosenberg, 1974; Scherer, 1965). Specifically, "the stimulus for new products and processes comes from (internal or external) research; the goal is to make commercial use of new knowhow $[\ldots]$. Therefore, it does not matter if a certain demand already exists or not" (Brem \& Voigt, 2009, p. 355). The rate and direction of innovation are determined by advances in science and technology and the availability of exploitable "technological opportunities" (Rosenberg, 1974). In particular, this perspective highlights the crucial role of a firm's technological capabilities (i.e., the firm's physical and knowledge capital stock) to develop new products and processes, emphasizing that, "to build up such a capital stock, inputs like R\&D investment or further education of the employees are necessary" (Horbach, 2008, p. 164). In more recent studies, an extension of this idea is that a key determinant of innovation is the cumulative knowledge invested to develop the firm's "absorptive capacity" (Cohen \& Levinthal, 1990; Zahra \& George, 2002) and exploit emerging opportunities (García-Quevedo et al., 2014; Nemet, 2009).

This framework appears to be suitable and especially useful for analyzing the propensity of family owned-managed firms to invest in innovation for several reasons. The DP and TP innovation impulses imply very different levels of risk and intensity of resource investments (as we discuss in detail in the following section). The literature on innovation behavior in family owned-managed firms considers the firm's resource endowment and the level of risk related to decisions to innovate as fundamental factors that influences this behavior (e.g., Nieto, Santamaria, \& Fernandez, 2015). Specifically, the distinction between market-pull (DP) and 
technology-push driven innovation (TP) is an important criterion for interpreting "how" family firms approach innovation (e.g., Nieto et al., 2015; De Massis et al., 2015).

This distinction implies that family owned-managed firms approach innovation decisions following paths that correspond with their risk preferences and their financial and managerial endowment (e.g., Nieto et al., 2015). The recent empirical study of De Massis et al. (2015) on product innovation in family owned-managed firms suggests that the average budget per innovation project is determined by jointly considering market-pull (DP) and technology-push (TP) driven innovation as well as the family goals and preferences. Therefore, these two innovation impulses may play a key role in determining the family management's influence on the firm's propensity to invest in innovation.

In the following, we consider these two different perspectives to develop our hypotheses on family firms' propensity to invest in innovation. Fig.1 illustrates our proposed research model.

(Insert Fig. 1 about here)

\subsection{The DP and TP effects on family firm innovation investment propensity}

The literature highlights that the DP and TP perspectives refer to two different innovation impulses (Brem and Voigt, 2009) with substantially different characteristics (Herstatt \& Lettl, 2004) (see Table 1).

(Insert Table 1 about here)

These differences lead to considering that the DP and TP innovation impulses may variously affect firms' propensity to invest in innovation, as we explain in the following.

Demand-pulled innovation investments are undertaken on "some reasonable expectation that there exists a market demand sufficiently large to justify that expenditure" (Mowery \& Rosenberg, 1979, p. 141), and therefore on the positive expectation of sales and profitability (Fontana \& Guerzoni, 2008). Therefore, the DP innovation impulse is characterized by low 
levels of sales/market-related uncertainty (Herstatt \& Lettl, 2004). Consequently, the timing and cash flows are easy to predict and more stable compared to technology-pushed innovation investments.

These characteristics may positively influence family firms' propensity to invest in innovation, as they are consistent with their "peculiar financial logic" (Gallo, Tapies, \& Cappunis, 2004, p. 315). In fact, family firms have a strong preference for internal over external financial resources (Romano et al., 2001; Sirmon \& Hitt, 2003) to safeguard family control of the business (Croci, Doukas, \& Gonec, 2011; González, Guzmán, Pombo, \& Trujillo, 2013; Mahérault 2004; Romano et al., 2001; Wu, Chua, \& Chrisman, 2007), and protect the family's socioemotional wealth (Gómez-Mejía et al., 2007). As a result, family firms are strongly dependent on internally generated funds (De Massis, Audretsch, Uhlaner, \& Kammerlander, 2018; Poutziouris, 2001) linked to operating cash flow and profitability. Thus, DP investments in innovation can be seen as a way of generating and ensuring stable and low-risk resource flows (compared to technology-pushed innovation), consistently with the family firm's preference for self-financing.

Moreover, the DP innovation impulse can stimulate a family firm's propensity to invest in innovation, as it implies low levels of R\&D expenditure (compared to technology-pushed innovation) (see Table 1). High R\&D investments generally require resorting to outside financial resources (Duran et al., 2016), but family firms are reluctant to raise money externally, preferring investments that protect the cash flow of the current business (Mork \& Yeung, 2003), despite potentially forgoing growth opportunities (González et al., 2013; Mahérault, 2004; Wu et al., 2007). This financial behavior may create financial constraints that could lead to limited investments in innovation (Duran et al., 2016; Gómez-Mejía et al., 2007) if the resources needed are higher than the firm's financial capacity. Instead, DP innovation implies low levels of R\&D expenditure, and may thus positively influence the family firm's 
propensity to invest in innovation. Formally stated:

H2. There is a positive association between the demand-pulled innovation impulse and family firms' propensity to invest in innovation.

On the other hand, technology-pushed innovation activities are not based on potential or existing market demand, and thus characterized by higher levels of sales/market-related uncertainty (compared to demand-pulled innovation) (see Table 1), making the timing and returns less easily predictable. Moreover, the literature highlights that technology-pushed innovation is also characterized by higher technological and time-to-market uncertainty, high $R \& D$ expenditure, and the longer duration of $R \& D$ activities (see Table 1).

All these aspects may exert a negative influence on family firms' innovation propensity for two main reasons. First, family firms are generally reluctant to invest significant resources in innovation, preferring less risky and less uncertain investments (Anderson, Duru, \& Reeb, 2012; Duran et al., 2016). Second, differently from demand-pulled innovation, the uncertainty of sales and profitability generated by technology-pushed innovation investments is less consistent with the family firm's financial logic based on the strong preference for selffinancing.

Moreover, the TP perspective highlights the firm's knowledge capital stock and its ability to develop absorptive capacity as key aspects of the innovation process (Nemet, 2009; Rosenberg, 1990). The firm's knowledge capital stock is strongly related to the human capital it can access (Horbach, 2008), yet family firms are characterized by a lack of qualified human capital and the difficulty of attracting it (Blanco-Mazagatos, de Quevedo-Puente, \& DelgadoGarcía, 2018; Carney, 1998; Miller \& Le Breton-Miller, 2005). Indeed, family firms need to open their management to non-family members to acquire knowledge that family members do not possess (De Massis et al., 2015, De Massis, Kotlar, Frattini, Chrisman, \& Nordqvist, 2016b), but the family firm's human resources management practices (such as favoritism 
toward family members and the perception of differences in treatment and monitoring between family and non-family members) (e.g., Madison, Daspit, Turner, \& Kellermanns, 2018) reduce the incentive for non-family members to invest in firm-specific knowledge (De Massis et al., 2015, 2016b) and to permanently join the firm (Colombo, De Massis, Piva, Rossi-Lamastra, \& Wright, 2014; Schulze, Lubatkin, Dino, \& Buchholtz, 2001; Schulze, Lubatkin, \& Dino, 2003).

These aspects can hamper the family firm's knowledge accumulation process as well as its absorptive capacity (Classen, Van Gils, Bammens, \& Carree, 2012). Consequently, in family firms, the TP innovation impulse may have negative effect on the propensity to invest in innovation. Thus, we propose the following hypothesis:

H3. There is a negative association between the technology-pushed innovation impulse and family firms' propensity to invest in innovation.

While most prior research on family firms focuses on a direct effect of family management on innovation inputs, we now hypothesize that innovation investment propensity is the result of the joint action of family management and the specific innovation impulse. Accordingly, below we propose the DP and TP innovation impulses as potential moderators in the relationship between family management and the firm's innovation propensity.

Demand-pulled innovation requires a low level of R\&D expenditure, and hence low uncertainty about its success and future returns, thus reducing the need for external financial resources. These characteristics determine low-risk investments in innovation and are likely to reduce the family management's reluctance to invest in innovation. Indeed, family managers are risk-averse in their investment decisions due to their fear of losing shareholding rights to non-family investors and their discretion to act. Moreover, family managers are reluctant to take excessive risks in order to protect their socioemotional wealth (Zahra, 2005). As a result, the DP innovation impulse should positively influence the relationship between family management and innovation propensity. 
Furthermore, the DP innovation impulse is typically related to incremental innovation strategies (Brem \& Voigt, 2009; Darroch \& McNoughton, 2002; Hersatt \& Lettl, 2004). The literature suggests that family management influences the firm's strategy by strengthening the focus on family-centered goals (Chrisman, Chua, De Massis, Minola, \& Vismara, 2016) and preserving the family's socioemotional wealth (Gómez-Mejia et al., 2007), which ultimately results in conservative strategies and short-term innovation projects related to incremental innovation (Li \& Daspit, 2016). Therefore, we argue that the DP innovation impulse should determine a less pronounced negative effect of family management on a firm's innovation propensity. Thus, we hypothesize:

H4. The demand-pulled innovation impulse moderates the relationship between family management and the family firm's propensity to invest in innovation. Specifically, an increase in the DP innovation impulse will lead to a weaker negative effect of family management on family firms' propensity to invest in innovation.

On the other hand, the TP innovation impulse can strengthen the negative relationship between family management and innovation investment propensity for a number of reasons. The TP impulse implies investments in innovation characterized by high uncertainty, high risk in terms of their success and returns, and a high level of R\&D expenditure, which can generate new knowledge and enhance the firm's ability to identify, assimilate, and exploit existing knowledge (Cohen \& Levinthal, 1989, 1990) (see Table 1). The literature suggests that in family owned-managed firms, the level of risk associated with the investment decision and the amount of resources available are the main factors that "make family involvement an influential characteristic in innovation processes" (Nieto et al., 2015, p. 382).

Consequently, the TP innovation impulse can lead family management to greater risk aversion regarding investment decisions, and lower willingness to invest in innovation. Indeed, in family-managed firms, the uncertainty and risk related to these investments may expose the 
family assets due to the close overlap of the family members' and the firm's wealth. Moreover, high $R \& D$ expenditure often calls for external resources, yet the family management is typically reluctant to share (or lose) decision-making control, and thus not inclined to access external capital or allow the entry of non-family investors (Diéguez-Soto et al., 2016).

Furthermore, the financing of high R\&D expenditure can generate high financial costs due to information asymmetry (the debt holders do not know the real value of the technology investment) and the intangible nature of the asset created by these investments (that cannot serve as collateral) (Hall, 2002). Finally, TP innovation refers to radical innovation strategies (Brem and Voigt, 2009; Darroch \& McNoughton, 2002; Hersatt \& Lettl, 2004), implying exploration-oriented activities characterized by risk-taking, research, experimentation, and the need for new external resources and skills for their integration with existing resources. These activities may lead to a reconfiguration of the firm's resources and power system, and thus the family managers' perception of the risk of uncertain effects on their socioemotional wealth (Carnes \& Ireland, 2013). Thus, we hypothesize that:

H5. The technology-pushed innovation impulse moderates the relationship between family management and the family firm's propensity to invest in innovation. Specifically, an increase in the TP innovation impulse will lead to a stronger negative effect of family management on family firms' propensity to invest in innovation.

\section{Methodology}

\subsection{Sample}

The data for this research was gathered from the EU-EFIGE/Bruegel-UniCredit Dataset (EFIGE Dataset) collected within the EFIGE project (European Firms in a Global Economy: Internal policies for external competitiveness) supported by the European Commission through its 7th Framework Program. The EFIGE Dataset contains qualitative and quantitative information on 14,759 manufacturing firms with more than nine employees in seven European 
countries. The data cover about 150 items related to R\&D and innovation, ownership, labor organization, financing, internationalization, and pricing policy. The data were collected in 2010 through a survey covering the years 2007 to 2009 . The first version of this dataset, relating to the period 2001-2003 (using the same questionnaire survey but focusing only on Italian companies), has been used in previous innovation management studies (e.g., Laursen, Masciarelli, \& Prencipe, 2012; Laursen, Masciarelli, \& Reichstein, 2016).

Our research focuses on all Italian small and medium-sized family firms (family SMEs) included in the EFIGE Dataset (except those with outliers or missing data regarding the variables of interest as described below). The criteria adopted to ensure the standard statistical representativeness of our sample and all the data included in the EFIGE Dataset are illustrated in detail in the descriptive document attached to the dataset and edited by Altomonte and Aquilante (2012). We referred to Italian family SMEs for three main reasons: family involvement is likely to be more prominent and relevant in influencing behaviors in smaller firms compared to larger firms (e.g., Chrisman et al., 2012); family SMEs have a relevant impact on economic growth (Audretsch, Keilbach, \& Lehmann, 2006; Memili et al., 2015); and the Italian industrial system is characterized by the prevalence of small and medium enterprises (SMEs) (99.9\% of total firms) (European Commission, 2017).

Italy is a particularly interesting context for studying firms' propensity to invest in innovation. In fact, Italian firms are characterized by levels of investments in innovation below the average of other European countries (CNR, 2018), and Italy ranks among the European countries defined as "moderate innovators" (European Commission, 2019). We adopted the European Commission's definition of SMEs, and therefore selected enterprises with fewer than 250 employees and an annual turnover not exceeding 50 million euro.

To identify the family firms, we used the following two criteria: the firm is directly or indirectly controlled by an individual or family-owned entity; the number (more than one) of 
entrepreneurs/executives (including middle management) related to the family that owns the firm. Although our focus is on family management, we also consider the family ownership criterion to take into account that an SME can typically be qualified as a family business if the family holds the majority of shares (Gómez-Mejia, Cruz, Berrone, \& De Castro, 2011), in accordance with previous studies on innovation investment decisions in family SMEs (e.g., Classen et al., 2014).

Moreover, family involvement in both ownership and management is consistent with prior studies aiming to capture the effect of family involvement on decision-making (e.g., De Massis et al., 2012; Kotlar, De Massis, Fang, \& Frattini, 2014a). We excluded all firms whose data were not available for all the variables and the period of interest. In addition, we removed the outliers using the z-scores method (re-centering and rescaling the data, and considering the +3 and -3 thresholds). After considering all companies in the EFIGE Dataset and respecting the above criteria, we obtained a final sample of 1,093 Italian family SMEs.

\subsection{Variables}

Dependent variable. Similarly to prior research measuring family SMEs' propensity to invest in innovation as a dummy variable (if or if not the firm reports positive innovation expenditure in the observed year) (e.g., Classen et al., 2014), we assessed innovation investment propensity adopting a binary variable (INN_PRO) equal to 1 if in 2009 the firm decided "not to postpone investments in product or process innovation", taking the value 0 otherwise, and referring to time $t+1$ (2009) with respect to the independent variables.

Independent variables. We assessed family involvement in the top management team (FTMT) using a continuous variable expressed as a percentage, and obtained by dividing the number of family members involved in the TMT by the total number of TMT members in 2008 (Minichilli, Corbetta, \& MacMillan, 2010). To capture the demand-pull innovation impulse, we referred to demand heterogeneity (consumer needs or market segments). This is consistent 
with the demand pull perspective emphasizing the importance of consumer (market) heterogeneity as drivers of innovation (e.g., Adner, 2002; Adner \& Levintal, 2001; Priem et al., 2012; von Hippel, 2005).

Indeed, demand heterogeneity allows acquiring knowledge from different geographic areas promoting new combinations of knowledge that can lead to more innovation (Xie \& Li 2015; Singh, 2008). Following prior research in the demand pull perspective using a firm's heterogeneous geographic markets as a proxy of demand heterogeneity (e.g., Xie \& Li, 2015; Piva \& Vivarelli, 2007), we assessed this variable by measuring the total number of countries to which a firm exported its products in 2008 (DEM_HETER).

To capture the technology push innovation impulse, we referred to firm technological capabilities. This is consistent with the technology push perspective emphasizing the importance of such capabilities (e.g., Baumol, 2002; Rosenberg, 1974), and consisting of the firm's physical and knowledge capital stock (Horbach, 2008) as drivers of innovation.

Specifically, following prior research underlining employee education as a way to build such capital stock, and arguing that "high qualification of employees" (measured as the share of highly qualified employees) is "interpretable as indicator of technological capabilities" (Horbach, 2008, p. 167), we assessed technology-push innovation impulse as the percentage of university graduates in the firms' workforce in 2008 (HIGH_QUAL).

Control variable. Prior literature has highlighted the relevance of firm age (AGE) as a predictor of entrepreneurial behavior (De Massis, Chirico, Kotlar, \& Naldi, 2014) and its influence on innovation performance (Craig \& Moores, 2006). AGE was measured as the number of years the firm has been established (Lee \& O'Neill, 2003) using three classes: less than 6 years; from 6 to 20 years; over 20 years. Firm size (EMPL) can influence innovation decision-making (Damanpour, 2010; Shefer \& Frenkel, 2005; Vaona \& Pianta, 2008), and was measured using total number of employees. Since business sectors are characterized by 
different degrees of technological opportunity, R\&D intensity, and innovation (Pavitt, 1984), we considering four subsectors: traditional, high tech, specialized, and economies of scale (Pavitt, 1984) (codified from 1 to 4 according to the above ordering). Given that the chief executive officer's age may influence strategic decision-making (Barker \& Mueller, 2002; Wiersema \& Bantel, 1992), we controlled for the CEO age effect (CEO_AGE) (Barker \& Mueller, 2002) using an ordinal variable coded in seven year classes.

Moreover, in family firms, the CEO may be a family member who typically has personal wealth invested in the firm and pursues non-financial goals (Chrisman, Chua, \& Litz, 2004). Thus, we controlled for the family CEO effect using a binary variable (FAM_CEO) equal to 1 if the CEO is a member of the controlling family, 0 otherwise. Finally, we considered that public policy and regulations can facilitate or inhibit a firm's investment in innovation through financial incentives (Herrera \& Sánchez-González, 2013), and hence included a binary variable (PUB) equal to 1 if the firm benefited from public sector financial incentives, 0 otherwise.

\subsection{Model}

To study the relationship between the set of independent variables and the dependent variable INN_PRO, we used logistic regression models (Models 1, 2, 3, and 4 in Table 4). Model 1 only includes the control variables, Model 2 includes FTMT, Model 3 includes DEM_HETER and HIGH_QUAL, Model 4 includes the interaction terms between DEM_HETER and FTMT, and HIGH_QUAL and FTMT.

Model 4 (the full model) is given by:

LN $($ INN_PRO $/(1-$ INN_PRO $))=\beta_{0}+\beta_{1} \cdot$ AGE $2+\beta_{2} \cdot$ AGE $3+\beta_{3} \cdot$ SECTOR $2+\beta_{4} \cdot$ SECTOR $3+\beta_{5} \cdot$ SECTOR $4+$ $\beta_{6} \cdot$ PUB $+\beta_{7} \cdot$ FAM_CEO $+\beta_{8} \cdot$ CEO_AGE $+\beta_{9} \cdot$ EMPL $+\beta_{10} \cdot$ FTMT $+\beta_{11} \cdot$ DEM_HETER $+\beta_{12} \cdot$ HIGH_QUAL + $\beta_{13} \cdot$ FTMT $\cdot$ DEM_HETER $+\beta_{14} \cdot$ FTMT $\cdot$ HIGH_QUAL $+\varepsilon$

where the four PAVITT categories of the SECTOR variable are represented using three dummy variables (SECTOR2, SECTOR3, and SECTOR4), and the three AGE modalities are 
represented with two dummy variables (AGE2 and AGE3).

\section{Results}

Tables 2 and 3 illustrate the descriptive statistics and the correlation matrix. To highlight some summary statistics of the dichotomous variables INN_PRO, PUB, and FAM_CEO, we inserted their percentages in the mean column of Table 2 . We observe that $45 \%$ of Italian family SMEs postponed investments in innovation. Moreover, $16 \%$ benefitted from public financial incentives. The average number of employees is 32.32 with the S.D. equal to 23.51. Moreover, our data show that $6 \%$ of the sample is composed of young firms (less than 6 years), $32 \%$ are 6-20 years old, and 62\% are more than 20 years old. Considering the four subsectors (traditional, high tech, specialized, and economies of scale), the percentage distribution is respectively: $54 \%, 17 \%, 24 \%$, and $5 \%$. The average percentage of FTMT is equal to $84.84 \%$ with the S.D. equal to 24.23. We highlight a negative significant correlation between INN_PRO and FTMT (-0.27). In addition, the other variables are significantly correlated with INN_PRO, and except for FAM_CEO, present a positive relationship. Table 4 shows the logistic regression models.

(Insert Tables 2, 3, and 4 about here)

The control variables are introduced in Model 1. We found a significant positive effect of AGE and the economies of scale subsector on INN_PRO, and a positive effect of CEO_AGE and EMPL. Instead, there is a statistically significant negative effect of FAM_CEO on INN_PRO. In Model 2, we introduced FTMT, which has a statistically negative effect on INN_PRO. In Model 3, the variables DEM_HETER and HIGH_QUAL were included. In terms of the direct effect of these variables on INN_PRO, we underline that only the former has a statistically significant positive effect on INN_PRO. In Model 4, we introduced the interaction terms DEM_HETER with FTMT, and HIGH_QUAL with FTMT. To better interpret the effect of DP on investment propensity, we observe that this effect becomes negative in the regression 
model that also considers the moderation effects (Model 4). Although the difference in value between the two coefficients of Models 3 and 4 is very low, this result would seem to suggest that the influence of the variable DP in family managed firms must be carefully considered, and therefore further investigated in future research on innovation in family SMEs.

Both interaction effects are positive and statistically significant in influencing INN_PRO. These two interaction effects have a similar interpretation, i.e., FTMT always has a negative effect on INN_PRO, but this negative effect is moderated by HIGH_QUAL and DEM_HETER. These moderating effects are such that for low levels of HIGH_QUAL or for low levels of DEM_HETER, the negative effect of FTMT on INN_PRO is much more pronounced if compared to when these two variables assume high values. Clearly, when HIGH_QUAL and DEM_HETER are high, the negative effect of FTMT on INN_PRO is dampened and remains negative (see Fig. 2).

(Insert Fig. 2 about here)

Model 4 shows a significant negative effect of DEM_HETER, which is naturally offset by the high significance of the interaction effect between DEM_HETER and FTMT that is opposite to and more significant than the direct negative effect of DEM_HETER on INN_PRO. Concerning the significance of Model 4 , this explains approximately $10 \%$ of the variability of the phenomenon. Our findings suggest that the effect of FTMT on INN_PRO is statistically significant (see Table 4), confirming H1.

Furthermore, we find a positive association between the demand-pulled innovation impulse and propensity to invest in innovation, confirming H2. In fact, Model 3 (Table 4) shows that the direct effect of DEM_HETER on INN_PRO is positive and statistically significant. Our results lead us to reject H3, as the regression coefficients of HIGH_QUAL, although positive, are not statistically significant. Conversely, we can confirm H4 given that the coefficients of 
the interaction term between DEM_HETER and FTMT are positive and statistically significant. Specifically, DEM_HETER has a moderating effect in the relationship between FTMT and INN_PRO: the higher the DEM_HETER, the weaker the negative effect of FTMT on INN_PRO. Concerning H5, this hypothesis must be rejected, as our results provide opposite evidence. Indeed, although the regression coefficients of the interaction terms between HIGH_QUAL and FTMT are positive and statistically significant, and thus HIGH_QUAL has a moderation effect, this effect is opposite to our hypothesis. Hence, as HIGH_QUAL increases, the negative effect of FTMT on INN_PRO decreases.

\subsection{Robustness check}

A fundamental challenge in empirical research, particularly in cross-sectional studies, is limiting the endogeneity issue, which is mainly caused by omitted variables and simultaneity.

To alleviate the endogeneity concerns, we reduced the possible impact of reverse causality by adopting a dependent variable taken at time $t+1$, whereas the independent variables are captured at time $t$. Moreover, since DEM_HETER and HIGH_QUAL may be endogenous in our models, we refer to two-stage least squares (2SLS) with multiple instrumental variables (IV). We performed the analysis using the R package AER with the function "ivreg". We used instrumental variables to compute the estimated values of the problematic predictors (DEM_HETER and HIGH_QUAL) in the first stage, and then used those computed values to estimate a regression model of the dependent variable (INN_PRO) in the second stage.

We identified the following set of IVs that met these requirements: CEO gender, as female CEOs are more likely to internationalize via export (Pergelova, Angulo-Ruiz, \& Yordanova, 2018) (determining more heterogeneity in consumer demand) and appear to be more qualified than their male counterparts (Donovan, 2015); the presence of benefits or bonuses for managers, as it represents a mechanism for retaining employees with high skills and qualifications, and some forms of compensation include training and educational development 
opportunities; export activities before 2008, since it may even take two or three years to transfer the knowledge inputs from foreign markets into product innovation (Salomon, 2006); possible affiliates in Italy or abroad, as affiliates in different geographic locations implies considering different markets and consumers (Singh, 2008), and therefore greater demand heterogeneity. Finally, we consider the existence of foreign competitors, which requires adopting a broader market perspective, and the greater geographic heterogeneity of possible consumers to achieve competitive innovations with a global application. All these were measured as dummy variables.

The findings of the 2SLS-IVs approach suggest accepting the null hypothesis that our model is equal to the 2SLS-IV, and thus that endogeneity is not a concern in our study. In fact, the instruments are not weak ( $p$-values lower than 0.05 ), with the Wu-Hausman test $p$-value equal to 0.283 , and the Sargan $p$-value equal to 0.613 , confirming that all the instruments are significant.

Furthermore, to check the robustness of our model, we also tested the three-interaction effects among FTMT, HIGH_QUAL, and DEM_HETER (Fig. 3). However, this interaction term was not included in our regression models, and we investigated this specific relationship for exploratory purposes only. The interaction term considers the combined effect of DEM_HETER and HIGH_QUAL in moderating the negative effect of FTMT on INN_PRO. Specifically, the negative effect of FTMT on INN_PRO is particularly strong if both DEM_HETER and HIGH_QUAL assume very low values. On the other hand, this negative effect is substantially lower if DEM_HETER and HIGH_QUAL assume very high values. Instead, the interaction effects in which either low HIGH_QUAL with high DEM_HETER, or HIGH HIGH_QUAL and low DEM_HETER are combined constitute intermediate cases. This triple interaction is statistically significant, further confirming that DEM_HETER and HIGH_QUAL play a very important role in modifying the negative effect of FTMT on 
INN_PRO in family firms. Fig. 3 highlights that both HIGH_QUAL and DEM_HETER moderate the effect of FTMT on INN_PRO, however, high DEM_HETER has a stronger moderating effect than high HIGH_QUAL (the slope in Fig. 3 is less steep for the high DEM_HETER-low HIGH_QUAL combination). ${ }^{2}$

(Insert Fig. 3 about here)

\section{Discussion and conclusions}

In this paper, we have analyzed the effect of DP and TP innovation impulses on the relationship between family management and innovation investment propensity. Drawing on the different characteristics associated with these two innovation impulses (as summarized in Table 1), we theorize their distinctive direct influence on family firms' propensity to invest in innovation, and their distinctive indirect effect on the relationship between family management and innovation investment propensity.

Consistent with prior studies (Chrisman \& Patel, 2012; Matzler et al., 2015; Sciascia et al., 2015), our results show a negative effect of family management on innovation propensity, thereby supporting H1. This reinforces the idea that family management leads to a lower propensity to invest in innovation due to increasing risk aversion and focusing on protecting the family's socioemotional wealth (Dièguez-Soto et al., 2016; Gómez-Mejía et al., 2007).

Our analysis of the direct effects of the DP and TP innovation impulses adds new insights to the debate on the factors that can drive or inhibit family firms' innovation investment propensity. Our hypotheses have been partially confirmed. Specifically, our expectation of the main effect of the DP impulse is confirmed (H2), highlighting that family firms' innovation investment propensity increases when innovation decisions are pulled by the market demand impulse. This suggests that the characteristics of the DP innovation impulse (see Table 1) are relevant for the innovation investment decisions of family firms, as they support: a) the specific

\footnotetext{
${ }^{2}$ The results from the robustness checks have been omitted for reasons of space, but are available upon request.
} 
financial logic adopted by family firms (Gallo et al., 2004); b) their reluctance to invest extensive resources in R\&D (Duran et al., 2016); and c) their risk aversion (Zahra, 2005).

Thus, our results provide clear evidence of the close link between these three specific family firm characteristics and their preference for demand-pulled innovation, as has indirectly emerged in recent studies. For example, De Massis et al. (2015), in their exploratory analysis based on a multiple case study, show that family firms: prefer innovation investments with a low level of market uncertainty (firm C interview in Appendix A of their study, p. 28); take innovation decisions with the intention of avoiding the excessive consumption of family resources (firm D interview in Appendix A of their study, p. 28); and prefer demand-pulled innovation projects (firms A, B, C, and E interviews in Appendix 1 of their study, pp. 22-23).

On the other hand, our hypothesis (H3) on the negative association between the TP innovation impulse and innovation investment propensity of family firms is not supported, as the result is not statistically significant. This "nonresult" (Bettis, Gambardella, Helfat, \& Mitchell, 2014) suggests that the relationship is more complex than hypothesized. Indeed, other arguments in a positive direction may explain the main effect of the TP innovation impulse. For example, the long-term orientation of family ownership (Zellweger, 2007) and family members in the TMT (Hoffmann, Wulf, \& Stubner, 2016) can increase the propensity to invest in long-term R\&D activities (implying greater risk) (Sciascia et al., 2015), and their "patient capital" (Lumpkin \& Brigham, 2011) can sustain investments in R\&D activities with long-term benefits (Schmid, Achleitner, Ampenberger, \& Kaserer, 2014). All these aspects are consistent with the technology-pushed innovation characteristics. Consequently, the direction of the main effect of the TP innovation impulse on family firm propensity to invest in innovation may be influenced by other contingent factors not considered in this study, providing an area ripe for future research.

Our hypothesis on the moderating role of the DP and TP innovation impulses ( $\mathrm{H} 4$ and $\mathrm{H} 5$ ) 
are also partially confirmed, allowing us to better understand how these two impulses affect family firms' innovation propensity. Specifically, Figs. 2 and 3 show that an increase in both the DP and TP innovation impulses leads to a weaker negative effect of family management on family firms' propensity to invest in innovation, confirming $\mathrm{H} 4$ but not H5. This result affirms that the characteristics of the DP innovation impulse support the family management risk orientation and the focus on financial and non-financial goals. Conversely, in our hypothesis development, we argued that the TP innovation impulse has characteristics that can reinforce the negative effect of family management on innovation investment propensity, but our results show the opposite effect. Thus, the relationship proposed in H5 is statistically significant but with the opposite sign. This result may be explained by the argument that the main positive effect of TP is reinforced in the case of family members involved in management. In fact, family managers have longer investment horizons (compared to external managers), do not face strong pressure on short-term results, and their behavior is not focused on maximizing their reputation (Schmid et al., 2014). Therefore, family managers may be inclined to invest in innovation activities characterized by long-term duration, high risk, uncertainty, and long-term returns (such as technology-pushed innovation). From this point of view, our results seem to suggest that in family firms characterized by family management, the long-term orientation has a greater weight on the propensity to invest in innovation than the risk aversion that prior research shows (e.g., Schmid et al., 2014).

Moreover, if we jointly consider the H3 "nonresult" and the H5 result, our study would seem to suggest that the TP innovation impulse is insufficient by itself to affect innovation investment propensity in family managed firms; instead, it is able to do so only in its interaction effect with family management. This interaction explanation contributes to advancing our understanding of the mechanisms behind the effect of family management, but future research is needed to assess whether our predictions hold. Comparing the effect of the DP and TP 
innovation impulses, Fig. 3 highlights that the negative effect of family management on innovation investment propensity is weaker in the case of a high DP innovation impulse, suggesting that the DP innovation impulse is a key factor shaping the innovation propensity of family firms, and confirming that family firms' innovation investments are more sensitive to demand-pull impulses.

Our findings can be better interpreted if we consider the time window covered, namely 2008-2009, a period marked by the start of the global financial crisis. Our results suggest that despite the effects of the crisis (in its early years), most Italian family SMEs reacted by continuing to invest in innovation, and during the crisis were particularly sensitive to demandpull impulses (less so to technology-push impulses).

This interpretation is supported by the European Commission (2009) survey on the effects of the crisis on the innovation of European firms. Specifically, the survey reveals that in the transition from the pre-crisis to the crisis period (2006 to 2009), some countries reduced their investments in innovation less than others and/or kept the level of investments in innovation constant (e.g., Germany and Italy). Furthermore, more than half the companies considered that the demand-side policies positively affected their innovation activities in this period, particularly DP impulses, such as increased demand from existing commercial clients, and new opportunities to expand existing or new markets. Our study suggests that in the specific context of family firms, this innovative behavior is related to two factors: the tendency of family firms to prefer self-financing to loan capital (access to which is even more difficult during a crisis), and their preference for innovation projects of shorter duration, certain market demand, and therefore less risky (particularly important in periods of uncertainty). Thus, our results offer a significant contribution to understanding innovation investment decisions in the specific context of Italian family firms during the global crisis.

These overall results offer several contributions to the literature on the innovation behavior 
of family firms, and generally innovation management studies. First, this study enriches existing knowledge on the effect of family management on innovation inputs in family firms, suggesting that the propensity to invest in innovation is the result of a joint action between family management and the specific innovation impulse. Our findings contribute to determining whether and how different innovation impulses lead to a more or less negative effect of family management on family firms' innovation investment propensity. Moreover, we shed light on which factors moderate the negative effect of family management on the innovation investment propensity of family firms. In fact, prior studies mostly focus on the direct effect of family management on innovation inputs, with consensus on the existence of a negative effect (Block, 2012; Kotlar et al., 2013). Building on this, the analysis of which factors moderate the negative effect of family management on innovation inputs allow us to better understand the heterogeneity among family firms and the differences in relation to non-family firms. Second, recent studies point out the existence of a knowledge gap at the intersection of the innovation management and family firm fields of study (Chrisman et al., 2015; De Massis et al., 2013). Our paper contributes to filling this gap by applying the demand-pull and technology-push theoretical framework developed in the context of family business organizations. Indeed, to the best of our knowledge, this is the first study that considers the effect of the DP and TP innovation impulses to examine the innovation behavior of family firms and identify which factors may drive or inhibit their propensity to invest in innovation. Moreover, in the field of empirical studies on family business innovation, another element that distinguishes our study from prior research is the adoption of a direct measure of the propensity to invest in innovation instead of using $\mathrm{R} \& \mathrm{D}$ expenditure (or intensity) as a proxy. This measure provides a more accurate assessment of family firms' propensity to invest in innovation, thus overcoming the limitations related to the use of $R \& D$ expenditure, which is usually underestimated in small firms (Archibugi \& Pianta, 1996; Patel \& Pavitt, 1995), and 
higher for innovation projects that are technology-pushed (see Table 1).

Furthermore, our study offers two main contributions to the innovation management literature. First, it highlights that the demand-pull and technology-push theoretical framework is also useful to explain the innovation behavior of family firms and specifically that market heterogeneity and highly qualified employees are able to affect the innovation behavior of family firms. Moreover, our results contribute to the debate on the juxtaposition between technology and demand as sources of innovation and/or their complementary role (Di Stefano et al., 2012), showing that both the DP and TP impulses can affect family firm innovation behavior, but the DP innovation impulse has a stronger influence on innovation investments. This suggests that the role and effect of these two innovation impulses also depend on the firm's specific nature and characteristics. Second, our study highlights that in family firms, the DP and TP innovation impulses exert their indirect effect by reducing the negative effect of family management on innovation investment propensity. Thus, we contribute to filling the gap in knowledge on the mechanisms with which firms can effectively exploit the effects of the DP and TP innovation impulses (Di Stefano et al., 2012). In particular, our results suggest that in the specific field of family business, the DP innovation impulse is able to positively influence the propensity to invest in innovation because it reduces the negative effect of FTMT. Therefore, family owned-managed firms can effectively exploit the effect of the DP innovation impulse through the relationship between FTMT and the propensity to invest in innovation.

\section{Implications, limitations, and future research}

Our results have implications for managers, practitioners advising family firms, and policymakers. First, the study cautions family business owners and managers to consider that the DP and TP innovation impulses may have different strengths in shaping their firm's propensity to invest in innovation. Specifically, our results show that the innovation demandpull impulse can significantly reduce the negative effect of family involvement in the TMT on 
the propensity to invest in innovation. This result may have important implications considering that: 1) the TMT is considered the most adept at defining and influencing strategic decisions; and 2) in family businesses, when family members are involved in the TMT, the FTMT decision-making process is the result of a complex dynamic of interacting and balancing the interests of the family component of the TMT with the non-family component (e.g., Binacci, Peruffo, Oriani, \& Minichilli, 2016; Vandekerkhof, Steijvers, Hendriks, \& Voordeckers, 2019). In fact, family managers usually also focus on socio-emotional and control objectives that can generate strategic inertia and limit innovation investments.

On the other hand, non-family managers strongly focus on financial goals, are less risk averse, and emotionally distant from the family system (e.g., Binacci et al., 2016). Therefore, managers need to consider that innovation budgets and plans based on the DP impulse can contribute to aligning and balancing the interests of family and non-family members of the TMT with regard to innovation investment decisions. As the characteristics of the DP innovation impulse fit better with the family members' SEW and control objectives, managers should create an appropriate process to support the DP impulse, exploit the demand-side policies promoted by policymakers, and strengthen the management team's DP approach.

This study provides a first step in guiding managers in this respect, suggesting the need to examine the extent to which DP and TP impulses can affect innovation in family firms.

Our results also have implications for practitioners advising family firms who need to carefully evaluate all the aspects described when providing innovation investment advice.

Moreover, given that innovation is a key driver of technological progress and economic growth, our study also has implications for policymakers. Our findings could help them decide under what circumstances the innovation investments of firms with family management should be promoted through DP or TP policies. In particular, policymakers can encourage innovation efforts by reducing the private cost of producing innovation (TP policy) or increasing the 
private payoff from successful innovation (DP policy) (Nemet, 2009). Given our results, policymakers should consider that the DP innovation impulse has a greater ability to stimulate the innovation propensity of family SMEs (compared to the TP impulse).

Specifically, the measures through which policymakers can expand the heterogeneity of markets (and therefore demand) can be direct and/or indirect. In terms of direct measures, policymakers might promote foreign commercial credit, enabling firms to offer customers competitive payment extensions or granting subsidized loans to SMEs for the promotion of products in foreign markets (through opening showrooms, stores, or participating in fairs or exhibitions), thereby stimulating foreign demand.

In terms of indirect measures, policymakers might refer to various financial incentives (e.g., investments and/or factual project studies) offered to firms that intend to develop their trade in foreign markets. Although our findings suggest that the TP impulse is less decisive than the DP impulse, support policies might involve the development of high-level training programs and staff qualifications in SMEs, as well as their direct involvement in developing such training programs (European Commission, 2015).

Our research might therefore assist policymakers in defining effective policies to support innovation in family firms and allocating public resources to DP versus TP activities.

This paper is not without limitations, which also offer opportunities for future research. First, our investigation focuses on Italian family firms. To increase the external validity of our results, future studies could consider different countries. Indeed, the literature suggests that innovation management processes may be affected by cultural contingencies (Hayton, George, \& Zahra, 2002). Secondly, although we controlled for potential endogeneity issues, we adopted a cross-sectional analysis given that our dataset covers the period 2007-2009. A longitudinal analysis could provide further evidence on causality directions among the variables, and thereby increase the validity of our results. Third, we measured the DP and TP variables 
following some prior studies developed in the mainstream innovation literature. Future research could employ further measures for the DP and TP innovation impulses to check whether our results hold. Indeed, prior studies suggest other possible measures for the DP innovation impulse, such as heterogeneity in consumer needs and requirements (Adner \& Levinthal, 2001), potential new markets (Vernon, 1966), and for the TP innovation impulse, employee further education (Horbach, 2008), firm-specific technological competences, and R\&D cost structure (Lee, 2003). This aspect assumes particular relevance for the TP variable, in light of the unexpected result of its moderating effect on the propensity to invest in innovation, as discussed in the previous section. Surely, this result is worth of investigation in future theoretical and empirical research in order to verify if there is an underlying theoretical explanation for it (i.e. how and why the high level of high qualification of employees reduces the negative effect exerted by family management on the propensity to invest in innovation) or if, instead, the measurement of the TP variable needs to be refined to fully understand its effect on the relationship between family management and firm propensity to invest in innovation.

Another limitation of our study is the selection of the sample and the family business definition adopted. As known, there is no consensus on the definition of a family business in the literature (see De Massis et al. (2012) for a recent overview). Certainly, an analysis of how our results might differ when changing the definition of family firms would enrich studies on their behavior. Finally, we focus on family SMEs. Future research could analyze the proposed research model in the context of large family firms to verify whether family firms of different sizes behave differently or not. Indeed, large firms may have different risk perceptions, resource endowments, access to resources, and degree of accumulated knowledge. Moreover, family firms differ in the extent to which they pay attention to their past and tradition (De Massis, Frattini, Kotlar, Petruzzelli, \& Wright, 2016a), and the role of innovation impulses in investment decisions may also vary, for instance, between multigenerational family firms that 
have a long tradition and first generation firms. Accordingly, future scholars could investigate this topic by distinguishing family firms of different generations.

In conclusion, our study offers theoretical arguments and empirical support for how the different innovation impulses influence the innovation investment propensity of family firms, paving the way for future research on this interesting topic.

\section{References}

Adner, R. (2002). When are technologies disruptive? A demand-based view of the emergence of competition. Strategic Management Journal, 23, 667-688.

Adner, R., \& Levinthal, D. (2001). Demand heterogeneity and technology evolution: Implications for product and process innovation. Management Science, 47(5), 611-628.

Altomonte, C., \& Aquilante, T. (2012). The EU-EFIGE/Bruegel-Unicredit Dataset. Bruegel Working Paper.

Anderson, R. C., Duru, A., \& Reeb, D. M. (2012). Investment policy in family controlled firms. Journal of Banking and Finance, 36(6), 1744-1758.

Archibugi, D., \& Pianta, M. (1996). Measuring technological change through patents and innovation surveys. Technovation, 16(9), 451-468.

Astrachan, J. H., \& Jaskiewicz, P. (2008). Emotional returns and emotional costs in privately held family businesses: Advancing traditional business valuation. Family Business Review, 21(2), 139-149.

Audretsch, D. B., Keilbach, M. C., \& Lehmann, E. E. (2006). Entrepreneurship and economic growth. Oxford: Oxford University Press.

Barker, V., \& Mueller, G. (2002). CEO characteristics and firm R\&D spending. Management Science, 48(6), 782-801.

Baumol, W. J. (2002). The Free-Market Innovation Machine-Analyzing the Growth Miracle of Capitalism. Princeton University Press, New Jersey

Bettis, R., Gambardella, A., Helfat, C., \& Mitchell, W. (2014). Quantitative empirical analysis in strategic management. Strategic Management Journal, 35(7), 949-953.

Binacci, M., Peruffo, E., Oriani, R., \& Minichilli, A. (2016). Are all non-family managers (NFMs) equal? The impact of NFM characteristics and diversity on family firm performance. Corporate Governance: An International Review, 24(6), 569-583.

Blanco-Mazagatos, V., de Quevedo-Puente, E., \& Delgado-García, J. B. (2018). Human resource practices and organizational human capital in the family firm: The effect of generational stage. Journal of Business Research, 84, 337-348.

Block, J. H. (2012). R\&D investments in family and founder firms: An agency perspective. Journal of Business Venturing, 27(2), 248-265.

Block, J. H., Miller, D., Jaskiewicz, P., \& Spiegel, F. (2013). Economic and technological importance of innovations in large family and founder firms: An analysis of patent data. Family Business Review, 26(2), 180-199. 
Blundell, R., Griffiths, R., \& Van Reenen, J. (1999). Market share, market value and innovation in a panel of British manufacturing firms. Review of Economic Studies, 66(3), 529-554.

Brem, A., \& Voigt, K. I. (2009). Integration of market pull and technology push in the corporate front end and innovation management-Insights from the German software industry. Technovation, 29(5), 351-367.

Calabrò, A., Vecchiarini, M., Gast, J., Campopiano, G., De Massis, A., \& Kraus, S. (2018). Innovation in family firms: A systematic literature review and guidance for future research. International Journal of Management Reviews 21(3), 317-355.

Carnes, C. M., \& Ireland, R. D. (2013). Familiness and innovation: Resource bundling as the missing link. Entrepreneurship Theory and Practice, 37(6), 1399-1419.

Carney, M. (1998). A management capacity constraint? Obstacles to the development of the overseas Chinese family business. Asia Pacific Journal of Management, 15(2), 137-162.

Carney, M. (2005). Corporate governance and competitive advantage in family-controlled firms. Entrepreneurship Theory and Practice, 29(3), 249-265.

Chen, H. L., \& Hsu, W. T. (2009). Family ownership, board independence, and R\&D investment. Family Business Review, 22(4), 347-362.

Chrisman, J. J., Chua, J. H., De Massis, A., Frattini, F., \& Wright, M. (2015). The ability and willingness paradox in family firm innovation. Journal of Product Innovation Management, 32(3), 310-318.

Chrisman, J. J., Chua, J. H., De Massis, A., Minola, T., \& Vismara, S. (2016). Management processes and strategy execution in family firms: From "what" to "how". Small Business Economics, 47(3), 719-734.

Chrisman, J. J., Chua, J. H., \& Litz, R. A. (2004). Comparing the agency costs of family and non-family firms: Conceptual issues and exploratory evidence. Entrepreneurship Theory and Practice, 28(4), 335-354.

Chrisman, J. J., Chua, J. H., Pearson, A. W., \& Barnett, T. (2012). Family involvement, family influence, and family-centered non-economic goals in small firms. Entrepreneurship Theory and Practice, 36(2), 267-293.

Chrisman, J. J., \& Patel, P. C. (2012). Variation in R\&D investment of family and non-family firms: Behavioural agency and myopic loss aversion perspective. Academy of Management Journal, 55(4), 976-997.

Chua, J. H., Chrisman, J. J., \& Steiner, L. P. (2003). Extending the theoretical horizon of family business research. Entrepreneurship Theory and Practice, 27(4), 331-338.

Classen, N., Carree, M., Van Gils, A., \& Peters, B. (2014). Innovation in family and non-family SMEs: An exploratory analysis. Small Business Economics, 42(3), 595-609.

Classen, N., Van Gils, A., Bammens, Y., \& Carree, M. (2012). Accessing resources from innovation partners: The search breadth of family SMEs. Journal of Small Business Management, 50(2), 191-215.

Cohen, W. M., \& Levin, R.C. (1989). Empirical studies of innovation and market structure. Handbook of industrial organization: Elsevier Publishers.

Cohen, W. M., \& Levinthal, D. A. (1989). Innovation and learning: The two faces of R\&D. The Economic Journal, 99(397), 569-596.

Cohen, W. M., \& Levinthal, D. A. (1990). Absorptive capacity: A new perspective on learning and innovation. Administrative Science Quarterly, 35(1), 128-152.

Colombo, M. G., De Massis, A., Piva, E., Rossi-Lamastra, C., \& Wright, M. (2014). Sales and employment changes in entrepreneurial ventures with family ownership: Empirical 
evidence from high-tech industries. Journal of Small Business Management, 52(2), 226245.

Craig, J. B. L., \& Moores, K. (2006). A 10-year longitudinal investigation of strategy, system, and environment on innovation in family firms. Family Business Review, 19(1), 1-10.

Crépon, B., Duguet, E., \& Mairesse, J. (1998). Research, innovation and productivity: An econometric analysis at the firm level. Economics of Innovation and New Technology, 7(2), $115-158$.

Croci, E., Doukas, J. A., \& Gonec, H. (2011). Family control and financing decisions. European Financial Management, 17(5), 860-897.

CNR (Consiglio Nazionale delle Ricerche) (2018). Relazione sulla ricerca e l'innovazione in Italia, Roma. Available at http://www.dsu.cnr.it/relazione-ricerca-innovazione-2019/

Damanpour, F. (2010). An integration of research findings of effects of firm size and market competition on product and process innovations. British Journal of Management, 21(4), 996-1010.

Darroch, J., \& McNoughton, R. (2002). Examining the link between knowledge management practices and types of innovation. Journal of Intellectual Capital, 3(3), 210-220.

De Massis, A., Audretsch, D., Uhlaner, L., \& Kammerlander, N. (2018). Innovation with limited resources: Management lessons from the German Mittelstand. Journal of Product Innovation Management, 35(1), 125-146.

De Massis, A., Chirico, F., Kotlar, J., \& Naldi, L. (2014). The temporal evolution of proactiveness in family firms: The horizontal S-curve hypothesis. Family Business Review, $27(1), 35-50$.

De Massis, A., Frattini, F., Kotlar, J., Petruzzelli, A. M., \& Wright, M. (2016a). Innovation through tradition: Lessons from innovative family businesses and directions for future research. Academy of Management Perspectives, 30(1), 93-116.

De Massis, A., Frattini, F., \& Lichtenthaler, U. (2013). Research on technological innovation in family firms: Present debates and future directions. Family Business Review, 26(1), 1031 .

De Massis, A., Frattini, F., Pizzurno, E., \& Cassia, L. (2015). Product innovation in family vs. non-family firms: An exploratory analysis. Journal of Small Business Management, 53(1), $1-36$.

De Massis, A., Kotlar, J., Frattini, F., Chrisman, J. J., \& Nordqvist, M. (2016b). Family governance at work: Organizing for new product development in family SMEs. Family Business Review, 29(2), 189-213.

De Massis, A., Kotlar, J., Mazzola, P., Minola, T., \& Sciascia, S. (2018). Conflicting selves: Family owners' multiple goals and self-control agency problems in private firms. Entrepreneurship Theory \& Practice, 42(4), 362-389.

De Massis, A., Sharma, P., Chua, J. H., \& Chrisman, J. J. (2012). Family business studies: An annotated bibliography. Cheltenham: Edward Elgar Publishing.

Di Stefano, G., Gambardella, A., \& Verona, G. (2012). Technology push and demand pull perspectives in innovation studies: Current findings and future research directions. Research Policy, 41(8), 1283-1295.

Diéguez-Soto, J., Manzaneque, M., \& Rojo-Ramírez, A. A. (2016). Technological innovation inputs, outputs, and performance: The moderating role of family involvement in management. Family Business Review, 29(3), 327-346. 
Donovan, G. (2015). Women Fortune 500 CEOs. Held to Higher Standards: American Management Association.

Dosi, G., \& Nelson, R. R. (2013). The evolution of technologies: an assessment of the state-ofthe-art. Eurasian Business Review, 3(1), 3-46.

Duran, P., Kammerlander, N., Van Essen, M., \& Zellweger, T. (2016). Doing more with less: Innovation input and output in family firms. Academy of Management Journal, 59(4), 12241264.

European Commission (2009). Innobarometer 2009. Analytical Report. https://ec.europa.eu/commfrontoffice/publicopinion/flash/fl_267_en.pdf

European Commission (2015). Report on the public consultation on the "New SME Policy". http://ec.europa.eu/DocsRoom/documents/8986/attachments/1/translations

European Commission (2017). 2017 SBA Fact Sheet Italy. https://ec.europa.eu/docsroom/documents/26562/attachments/16/translations/en/renditions /native. Accessed 4 August 2018.

European Commission (2019). European Innovation Scoreboard. https://ec.europa.eu/growth/industry/innovation/facts-figures/scoreboards_en. Accessed 30 July 2019.

Filser, M., Brem, A., Gast, J., Kraus, S., \& Calabrò, A. (2016). Innovation in family firmsExamining the inventory and mapping the path. International Journal of Innovation Management, 20(6), 1650054.

Filser, M., De Massis, A., Gast, J., Kraus, S., \& Niemand, T. (2018). Tracing the roots of innovativeness in family SMEs: The effect of family functionality and socioemotional wealth. Journal of Product Innovation Management, 35(4), 609-628.

Fontana, R., \& Guerzoni, M. (2008). Incentives and uncertainty: An empirical analysis of the impact of demand on innovation. Cambridge Journal of Economics, 32(6), 927-946.

Gallo, M. A., Tapies, J., \& Cappunis, K. (2004). Comparison of family and non-family business: Financial logic and personal preferences, Family Business Review, 17(4), 303318.

García-Quevedo, J., Pellegrino, G., \& Vivarelli, M. (2014). R\&D drivers and age: Are young firms different? Research Policy, 43(9), 1544-1556.

Gerpott, T. J. (2005). Strategisches technologie- und innovationsmanagement. SchäfferPoesche, Stuttgart.

Gomez-Mejia, L. R., Cruz, C., Berrone, P., \& De Castro, J. (2011). The bind that ties: Socioemotional wealth preservation in family firms. Academy of Management Annals, 5(1), 653-707.

Gómez-Mejía, L. R., Haynes, K. T., Núñez-Nickel, M., Jacobson, K. J., \& Moyano-Fuentes, J. (2007). Socioemotional wealth and business risks in family-controlled firms: Evidence from Spanish olive oil mills. Administrative Science Quarterly, 52(1), 106-137.

González, M., Guzmán, A., Pombo, C., \& Trujillo, M. A. (2013). Family firms and debt: risk aversion versus risk of losing control. Journal of Business Research, 66(11), 2308-2320.

Hall, B. (2002). The financing of research and development. Oxford Review of Economic Policy, 18, 35-51.

Hall, B. H., \& Lerner, J. (2010). The financing of R\&D and innovation. Handbook of the economics of innovation. Elsevier: North Holland.

Hayton, J. C., George, G., \& Zahra, S. A. (2002). National culture and entrepreneurship. A review of behavioral research. Entrepreneurship Theory and Practice, 26(4), 33-52. 
Herrera, L., \& Sánchez-González, G. (2013). Firm size and innovation policy. International Small Business Journal, 31(2), 137-155.

Herstatt, C., \& Lettl, C. (2004). Management of "technology push" development projects. International Journal of Technology Management, 27(2-3), 155-175.

Hoffmann, C., Wulf, T., \& Stubner, S. (2016). Understanding the performance consequences of family involvement in the top management team: the role of long term orientation. International Small Business Journal, 34(3), 345-368.

Holmstrom, B. B. (1989). Agency costs and innovation. Journal of Economics Behaviour and Organization, 12(3), 305-327.

Horbach, J. (2008). Determinants of environmental innovation-New evidence from German panel data sources. Research Policy, 37(1), 163-713.

Kotlar, J., \& De Massis, A. (2013). Goal setting in family firms: Goal diversity, social interactions, and collective commitment to family-centered goals. Entrepreneurship Theory and Practice, 37(6), 1263-1288.

Kotlar, J., De Massis, A., Fang, H., \& Frattini, F. (2014a). Strategic reference points in family firms. Small Business Economics, 43(3), 597-619.

Kotlar, J., De Massis, A., Frattini, F., Bianchi, M., \& Fang, H. (2013). Technology acquisition in family and non-family firms: A longitudinal analysis of Spanish manufacturing firms. Journal of Product Innovation Management, 30(6), 1073-1088.

Kotlar, J., De Massis, A., Frattini, F., \& Kammerlander N. (2019). Motivation gaps and implementation traps: The paradoxical and time-varying effects of family ownership on firm absorptive capacity. Journal of Product Innovation Management, https://doi.org/10.1111/jpim.12503.

Kotlar, J., Fang, H., De Massis, A., \& Frattini, F. (2014b). Profitability goals, control goals, and the R\&D investment decisions of family and nonfamily firms. Journal of Product Innovation Management, 31(6), 1128-1145.

Kotlar, J., Signori, A., De Massis, A., \& Vismara, S. (2018). Financial wealth, socioemotional wealth and IPO underpricing in family firms: A two-stage gamble model. Academy of Management Journal, 61(3), 1-27.

Kraiczy, D., Hack, A., \& Kellermans, F.W. (2014). New product portfolio performance in family firms. Journal of Business Research, 67(6), 1065-1073.

Kraus, S., Pohjola, M., \& Koponen, A. (2012). Innovation in family firms: an empirical analysis linking organizational and managerial innovation to corporate success. Review of Managerial Science, 6(3), 265-286.

La Porta, R., Lopez-de-Silanes, F., \& Shleifer, A. (1999). Corporate ownership around the world. Journal of Finance, 54(2), 471-517.

Laursen, K., Masciarelli, F., \& Prencipe, A. (2012). Trapped or spurred by the home region? The effects of potential social capital on involvement in foreign markets for goods and technology. Journal of International Business Studies, 43(9), 783-807.

Laursen, K., Masciarelli, F., \& Reichstein, T. (2016). A matter of location: The role of regional social capital in overcoming the liability of newness in R\&D acquisition activities. Regional Studies, 50(9), 1537-1550.

Le Breton Miller, I., \& Miller, D. (2006). Why do some family businesses out compete? Governance, long term orientations, and sustainable capability. Entrepreneurship Theory and Practice, 30(6), 731-746. 
Lee, C. Y. (2003). A simple theory and evidence on the determinants for firm R\&D. Economics of Innovation and New Technology, 12(5), 385-396.

Lee, P. M., \& O’Neill, H. M. (2003). Ownership structure and R\&D investment of US and Japanese firms: Agency and stewardship perspective. Academy of Management Journal, $46(2), 212-225$.

Levin, R. C., Klevorick, A. K., Nelson, R. R., Winter, S. G., Gilbert, R., \& Griliches, Z. (1987). Appropriating the returns from industrial research and development. Brookings Papers on Economic Activity 3, 783-820.

Li, Z., \& Daspit, J. J. (2016). Understanding family firm innovation heterogeneity: A typology of family governance and socioemotional wealth intentions. Journal of Family Business Management, 6(2), 103-121.

Lumpkin, T., \& Brigham, K. (2011). Long-term orientation and intertemporal choice in family firms. Entrepreneurship Theory and Practice, 35(6), 1149-1169.

Madison, K., Daspit, J. J., Turner, K., \& Kellermanns, F. W. (2018). Family firm human resource practices: Investigating the effects of professionalization and bifurcation bias on performance, Journal of Business Research, 84, 327-336,

Mahérault, L. (2004). Is there any specific equity route for small and medium-sized family businesses? The French experience. Family Business Review, 17(3), 123-132.

Matzler, K., Veider, V., Hautz, J., \& Stadler, C. (2015). The impact of family ownership, management, and governance on innovation. Journal of Product Innovation Management, 32(3), 319-333.

Memili, E., Fang, H., Chrisman, J. J., \& De Massis, A. (2015). The impact of small- and medium-sized family firms on economic growth. Small Business Economics, 45(4), 771785 .

Miller, D., \& Le Breton-Miller, I. (2005). Managing for the long run: Lessons in competitive advantage from great family businesses. Boston, MA: Harvard Business School Press.

Minichilli, A., Corbetta, G., \& MacMillan, I. C. (2010). Top management teams in familycontrolled companies: 'Familiness', 'faultlines', and their impact on financial performance. Journal of Management Studies, 47(2), 205-222.

Morck, R., \& Yeung, B. (2003). Agency problems in large family business groups. Entrepreneurship Theory and Practice, 27(4), 367-382.

Mowery, D., \& Rosenberg, N. (1979). The influence of market demand upon innovation: a critical review of some recent empirical studies. Research Policy, 8(2), 102-153.

Munari, F., Oriani, R., \& Sobrero, M. (2010). The effects of owner identity and external governance systems on R\&D investments: A study of Western European firms. Research Policy, 39(8), 1093-1104.

Muñoz-Bullon, F., \& Sanchez-Bueno, M. (2011). The impact of family involvement on the R\&D intensity of publicly traded firms. Family Business Review, 24(1), 62-70.

Myers, S., \& Marquis, D. (1969). Successful industrial innovation: A study of factors underlying innovation in selected firms. National Science Foundation, available at http://library.wur.nl/WebQuery/clc/423564. Accessed 31 January 2018.

Naldi, L., Nordqvist, M., Sjöberg, K., \& Wiklund, J. (2007). Entrepreneurial orientation, risk taking, and performance in family firms. Family Business Review, 20(1), 33-47.

Nemet, G. (2009). Demand-pull, technology-push, and government-led incentives for nonincremental technical change. Research Policy, 38, 700-709.

Nieto, M. J., Santamaria, L., \& Fernandez, Z. (2015). Understanding the innovation behavior of family firms. Journal of Small Business Management, 53(2), 382-399. 
Patel, P., \& Pavitt, K. (1995). Patterns of technological activity: Their measurement and interpretation. Handbook of the economics of innovation and technological change (pp. 1451), Oxford: Blackwell.

Pavitt, K. (1984). Sectoral patterns of technical change: Towards a taxonomy and a theory. Research Policy, 13(6), 343-373.

Pergelova, A., Angulo-Ruiz, F., \& Yordanova, D. I. (2018). Gender and international entry mode. International Small Business Journal, 36(6), 662-685.

Piva, M., \& Vivarelli, M. (2007). Is demand-pulled innovation equally important in different groups of firms? Cambridge Journal of Economics, 31(5), 691-710.

Poutziouris, P. (2001). The views of family companies on venture capital: Empirical evidence from the UK small to medium-size enterprising economy. Family Business Review, 14(3), 277-291.

Priem, R., Li, S., \& Carr, J. (2012). Insights and new directions from demand side approaches to strategy, innovation and entrepreneurship research. Journal of Management Review, 38(1), 346-374.

Randolph, R. V., Alexander, B. N., Debicki, B. J., \& Zajkowski, R. (2019). Untangling noneconomic objectives in family \& non-family SMEs: A goal systems approach, Journal of Business Research, 88, 317-332.

Roessl, D., Fink, M., \& Kraus, S. (2010). Are family firms fit for innovation? Towards an agenda for empirical research. International Journal of Entrepreneurial Venturing, 2(3-4), 366-380.

Romano, C. A., Tanewski, G. A., \& Smyrnios, K. X. (2001). Capital structure decision making: A model for family business. Journal of Business Venturing, 16(3), 285-310.

Rosenberg, N. (1974). Science, invention, and economic growth. Economic Journal, 84(333), 90-108.

Rosenberg, N. (1982). Inside the black box: Technology and economics. New York: Cambridge University Press.

Rosenberg, N. (1990). Why do firms do basic research (with their own money)? Research Policy, 19(2), 165-174.

Salomon, R. M. (2006). Spillovers to foreign market participants: assessing the impact of export strategies on innovative productivity. Strategic Organization, 4(2), 135-164.

Sarja, J. (2015). Key factors of successful technology push projects in the ICT context: A review of the literature. International Journal of Information Technology and Management, 14(4), 253-273.

Scherer, F. M. (1965). Firm size, market structure, opportunity, and the output of patented inventions. American Economic Review, 55(5), 1097-1125.

Scherer, F. M. (1982). Demand-pull and technological invention: Schmookler revisited. The Journal of Industrial Economics, 30(3), 225-237.

Schmid, T., Achleitner, A. K., Ampenberger, M., \& Kaserer, C. (2014). Family firms and R\&D behavior-New evidence from a large-scale. Research Policy, 43, 233-244.

Schmookler, J. (1966). Invention and economic growth. Cambridge, MA: Harvard University Press.

Schulze, W. S., Lubatkin, M. H., \& Dino, R. N. (2003). Exploring the agency consequences of ownership dispersion among the directors of private family firms. Academy of Management Journal, 46(2), 179-194.

Schulze, W. S., Lubatkin, M.H., Dino, R. N., \& Buchholtz, A. K. (2001). Agency relationship in family firms: Theory and evidence. Organization Science, 12(2), 99-116. 
Sciascia, S., Nordqvist, M., Mazzola, P., \& De Massis, A. (2015). Family ownership and R\&D intensity in small-and medium-sized firms. Journal of Product Innovation Management, $32(3), 349-360$.

Shefer, D., \& Frenkel, A. (2005). R\&D, firm size and innovation: An empirical analysis. Technovation, 25(1), 25-32.

Singh, J. (2008). Distributed R\&D, cross-regional knowledge integration and quality of innovative output. Research Policy, 37, 77-96.

Sirmon, D. G., Arregle, J. L., Hitt, M. A., \& Webb, J. W. (2008). The role of family influence in firms' strategic responses to threat of imitation. Entrepreneurship Theory and Practice, 32(6), 979-998.

Sirmon, D. G., \& Hitt, M. A. (2003). Managing resources: Linking unique resources, management, and wealth creation in family firms. Entrepreneurship Theory and Practice, 27(4), 339-358.

Sorescu, A. B., Chandy, R. K., \& Prabhu, J. C. (2003). Sources and financial consequences of radical innovation: Insight from pharmaceuticals. Journal of Marketing, 67(4), 82-102.

Vaona, A., \& Pianta, M. (2008). Firm size and innovation in European manufacturing. Small Business Economics, 30(3), 283-299.

Vernon, R. (1966). International investment and international trade in product cycle. Quarterly Journal of Economics, 80(2), 190-207.

Von Hippel, E. (1976). The dominant role of users in the scientific instrument innovation process. Research Policy, 5(3), 212-239.

Von Hippel, E. (2005). Democratizing innovation. Cambridge, MA: MIT Press.

Vandekerkhof, P., Steijvers, T., Hendriks, W., \& Voordeckers, W. (2019). The effect of nonfamily managers on decision-making quality in family firm TMTs: The role of intraTMT power asymmetries. Journal of Family Business Strategy, https://doi.org/10.1016/j.jfbs.2019.01.002.

Wiersema, M. F., \& Bantel, K. A. (1992). Top management team demography and corporate strategic change. Academy of Management Journal, 35(1), 91-121.

Wu, Z., Chua, J. H., \& Chrisman, J. J. (2007). Effects of family ownership and management on small business equity financing. Journal of Business Venturing, 22(6), 726-751.

Xie, Z., \& Li, J. (2015). Demand heterogeneity, learning diversity and innovation in an emerging economy. Journal of International Management, 21(4), 277-292.

Zahra, S. A. (2005). Entrepreneurial risk taking in family firms. Family Business Review, 18(1), 23-40.

Zahra, S. A., \& Fescina, M. (1991). Will leveraged buyouts kill U.S. corporate research \& development? The Executive, 5(4), 7-21.

Zahra, S. A., \& George, G. (2002). Absorptive capacity: A review, reconceptualization, and extension. Academy of Management Review, 27(2), 185-203.

Zellweger, T. (2007). Time horizon, cost and equity capital, and generic investment strategies of firms. Family Business Review, 20(1), 1-15. 


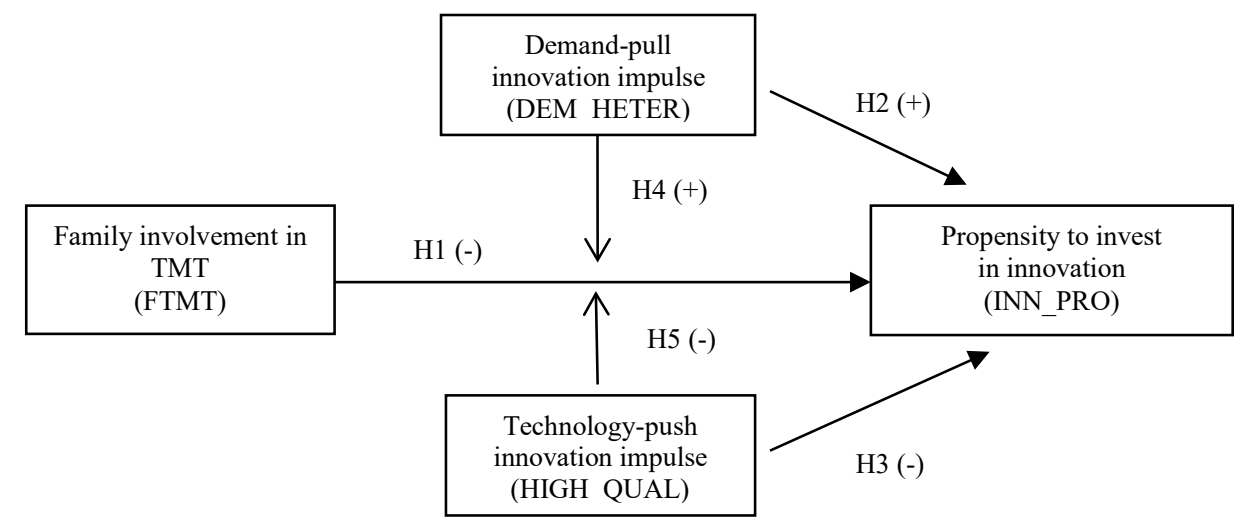

Fig. 1. Research Model
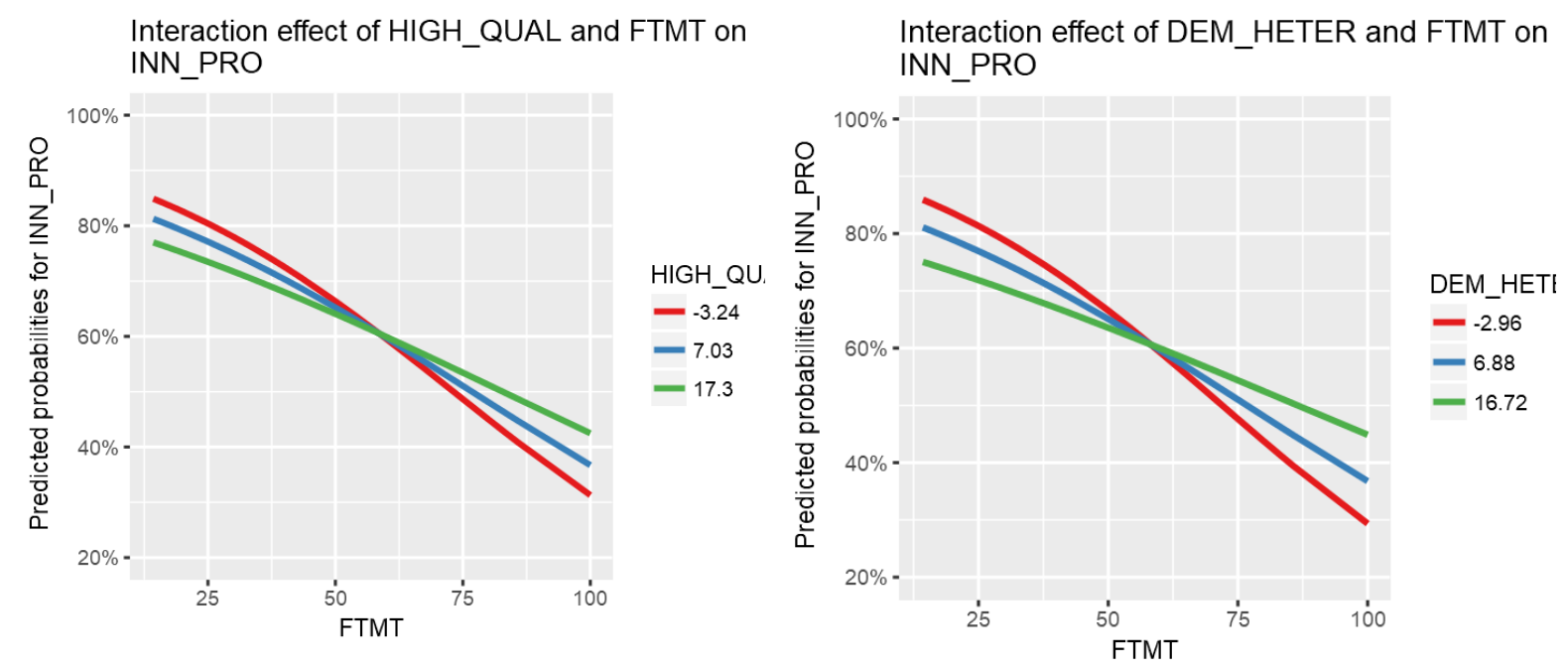

Fig. 2. Moderation effect of demand heterogeneity (DEM_HETER) and high qualification of employees (HIGH_QUAL) on the relation between family management (FTMT) and innovation investment propensity (INN_PRO), separately for each moderator. 


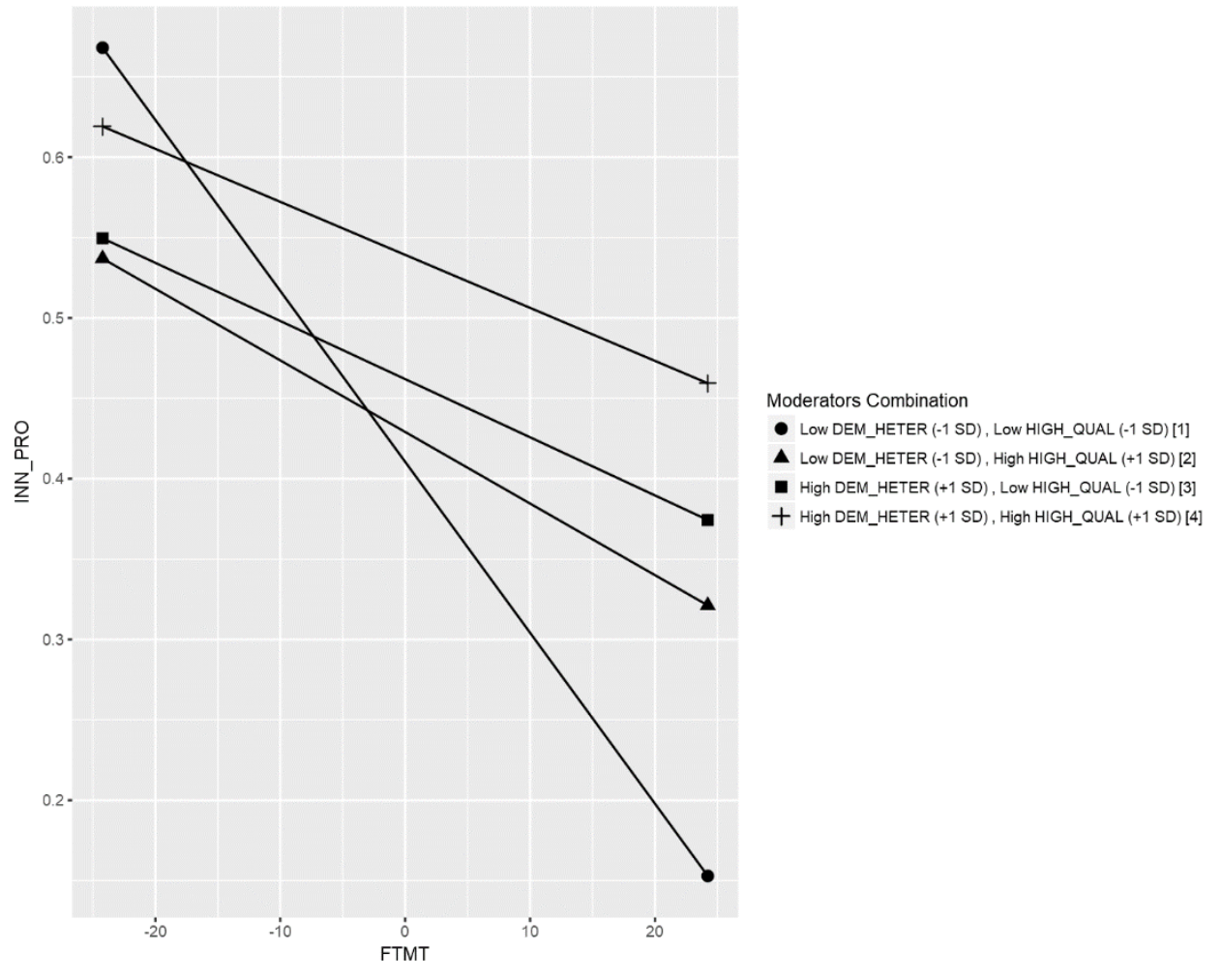

Fig. 3. Moderation effect of demand heterogeneity (DEM_HETER) and high qualification of employees (HIGH_QUAL) on the relation between family management (FTMT) and innovation investment propensity (INN_PRO).

Table 1

Summary of the differences between the DP and TP innovation impulses

\begin{tabular}{|c|c|c|c|}
\hline Attribute & Demand-pull & Technology-push & Selected references \\
\hline Technological uncertainty & Low & High & \multirow{8}{*}{$\begin{array}{l}\text { Brem and Voigt (2009); } \\
\text { Gerpott (2005); } \\
\text { Hersatt and Lettl (2004); } \\
\text { Sarja (2015) }\end{array}$} \\
\hline R\&D expenditure & Low & High & \\
\hline R\&D duration & Short & Long & \\
\hline Sales-market related uncertainty & Low & High & \\
\hline Time-to-market & Certain/Known & $\begin{array}{l}\text { Uncertain/ } \\
\text { unknown }\end{array}$ & \\
\hline R\&D customer integration & Easy & Difficult & \\
\hline Types of market research & $\begin{array}{l}\text { Quantitative/ } \\
\text { verifying }\end{array}$ & $\begin{array}{l}\text { Qualitative/ } \\
\text { discovering }\end{array}$ & \\
\hline The need to change customer behavior & Minimal & Extensive & \\
\hline $\begin{array}{l}\text { Relevance of the firm's knowledge capital } \\
\text { stock }\end{array}$ & Low & High & \multirow{2}{*}{$\begin{array}{l}\text { Horbach (2008); } \\
\text { García-Quevedo et al. } \\
\text { (2014); Nemet (2009); } \\
\text { Rosenberg (1990) }\end{array}$} \\
\hline Relevance of the firm's absorptive capacity & Low & High & \\
\hline
\end{tabular}

Note: adapted from Brem and Voigt (2009, p. 356) 
Table 2

Descriptive statistics

\begin{tabular}{|c|c|c|c|c|c|}
\hline Variables & mean & $s d$ & median & $\min$ & $\max$ \\
\hline INN_PRO & $0.45^{*}$ & & 0 & 0 & 1 \\
\hline AGE & & & 3 & 1 & 3 \\
\hline SECTOR & & & & 1 & 4 \\
\hline PUB & $0.16^{*}$ & & & 0 & 1 \\
\hline FAM_CEO & $0.97 *$ & & 1 & 0 & 1 \\
\hline CEO_AGE & & & 5 & 1 & 7 \\
\hline EMPL & 32.32 & 23.51 & 25 & 10 & 154 \\
\hline FTMT & 84.48 & 24.23 & 100 & 14.29 & 100 \\
\hline DEM_HETER & 6.88 & 9.84 & 3 & 0 & 85 \\
\hline HIGH_QUAL & 7.03 & 10.27 & 4.55 & 0 & 100 \\
\hline
\end{tabular}

Note: $N=1093$. “*”percentage of cases.

Table 3

Correlation Matrix

\begin{tabular}{|c|c|c|c|c|c|c|c|c|}
\hline & INN_PRO & $A G E$ & $P U B$ & FAM_CEO & $C E O \_A G E$ & $E M P L$ & $F T M T$ & DEM_HETER \\
\hline \multicolumn{9}{|l|}{$I N N \_P R O$} \\
\hline$A G E$ & $0.11^{* * *}$ & & & & & & & \\
\hline$P U B$ & 0.05 & -0.03 & & & & & & \\
\hline FAM_CEO & $-0.06^{*}$ & 0.04 & 0.00 & & & & & \\
\hline$C E O \_A G E$ & $0.11^{* * *}$ & $0.17^{* * *}$ & -0.03 & 0.02 & & & & \\
\hline$E M P L$ & $0.10^{* *}$ & $0.14^{* * *}$ & 0.05 & -0.04 & 0.06 & & & \\
\hline FTMT & $-0.27^{* * *}$ & $-0.07^{*}$ & -0.06 & $0.15^{* * *}$ & -0.03 & $-0.23^{* * *}$ & & \\
\hline DEM_HETER & $0.12^{* * *}$ & $0.10^{* *}$ & $0.07^{*}$ & -0.04 & $0.09^{* *}$ & $0.24^{* * *}$ & $-0.13^{* * *}$ & \\
\hline$H I G H \_Q U A L$ & $0.10^{* * *}$ & 0.03 & $0.13^{* * *}$ & 0.00 & 0.03 & 0.03 & $-0.17^{* * * *}$ & $0.18^{* * *}$ \\
\hline
\end{tabular}


Table 4

Logistic regression models

\begin{tabular}{|c|c|c|c|c|c|c|c|c|}
\hline & \multicolumn{2}{|c|}{ Model 1} & \multicolumn{2}{|c|}{ Model 2} & \multicolumn{2}{|c|}{ Model 3} & \multicolumn{2}{|c|}{ Model 4} \\
\hline & coeff & $\begin{array}{c}\text { std. } \\
\text { Error }\end{array}$ & coeff & $\begin{array}{c}\text { std. } \\
\text { Error }\end{array}$ & coeff & $\begin{array}{c}\text { std. } \\
\text { Error }\end{array}$ & coeff & $\begin{array}{c}\text { std. } \\
\text { Error }\end{array}$ \\
\hline (Intercept) & $-1.1246 *$ & 0.491 & 0.5466 & 0.551 & 0.4375 & 0.557 & $1.3799 *$ & 0.620 \\
\hline \multicolumn{9}{|l|}{ as.factor(AGE) } \\
\hline as.factor(AGE)2 & 0.3375 & 0.312 & 0.3607 & 0.321 & 0.3800 & 0.323 & 0.3301 & 0.322 \\
\hline as.factor $(A G E) 3$ & $0.6650 *$ & 0.303 & $0.6498 *$ & 0.311 & $0.6444 *$ & 0.313 & 0.6024 & 0.312 \\
\hline \multicolumn{9}{|l|}{ as.factor(SECTOR) } \\
\hline as.factor(SECTOR)2 & 0.1959 & 0.169 & 0.0814 & 0.175 & 0.0313 & 0.177 & 0.0361 & 0.178 \\
\hline as.factor(SECTOR)3 & 0.1369 & 0.151 & 0.0588 & 0.155 & 0.0457 & 0.156 & 0.0546 & 0.158 \\
\hline as.factor(SECTOR)4 & $0.7725 *$ & 0.358 & 0.4619 & 0.368 & 0.2946 & 0.377 & 0.2759 & 0.375 \\
\hline PUB & 0.2791 & 0.167 & 0.2329 & 0.172 & 0.1864 & 0.174 & 0.1781 & 0.175 \\
\hline FAM_CEO & $-0.7097 *$ & 0.347 & -0.3775 & 0.363 & -0.3760 & 0.366 & -0.4059 & 0.365 \\
\hline CEO_AGE & $0.1597 * *$ & 0.053 & $0.1631 * *$ & 0.055 & $0.1543 * *$ & 0.055 & $0.1442 * *$ & 0.056 \\
\hline EMPL & $0.0063 *$ & 0.003 & 0.0019 & 0.003 & 0.0008 & 0.003 & 0.0014 & 0.003 \\
\hline FTMT & & & $0.0213 * * *$ & 0.003 & ${ }_{0.0207}^{-} * * *$ & 0.003 & $0.0305 * * *$ & 0.004 \\
\hline DEM_HETER & & & & & $0.0138 *$ & 0.007 & $-0.0448 *$ & 0.023 \\
\hline HIGH_QUAL & & & & & 0.0078 & 0.007 & -0.0288 & 0.019 \\
\hline FTMT:DEM_HETER & & & & & & & $0.0007 * *$ & 0.000 \\
\hline FTMT:HIGH_QUAL & & & & & & & $0.0005 *$ & 0.000 \\
\hline Observations & \multicolumn{2}{|c|}{1093} & \multicolumn{2}{|c|}{1093} & \multicolumn{2}{|c|}{1093} & \multicolumn{2}{|c|}{1093} \\
\hline AIC & \multicolumn{2}{|c|}{1480.869} & \multicolumn{2}{|c|}{1422.618} & \multicolumn{2}{|c|}{1420.418} & \multicolumn{2}{|c|}{1412.326} \\
\hline -2 Log-Likelihood & \multicolumn{2}{|c|}{1460.869} & \multicolumn{2}{|c|}{1400.618} & \multicolumn{2}{|c|}{1394.418} & \multicolumn{2}{|c|}{1382.326} \\
\hline $\mathrm{X}_{\text {deviance }}^{2}$ & \multicolumn{2}{|c|}{$\mathrm{p}=.000$} & \multicolumn{2}{|c|}{$\mathrm{p}=.000$} & \multicolumn{2}{|c|}{$\mathrm{p}=.000$} & \multicolumn{2}{|c|}{$\mathrm{p}=.000$} \\
\hline Hosmer-Lemeshow- $\mathrm{X}^{2}$ & \multicolumn{2}{|c|}{$9.755 ; p=.283$} & \multicolumn{2}{|c|}{$7.641 ; p=.469$} & \multicolumn{2}{|c|}{$14.970 ; p=.060$} & \multicolumn{2}{|c|}{$4.631 ; p=.796$} \\
\hline
\end{tabular}

